\title{
PENGEMBANGAN MODEL LATIHAN FLEKSIBILITAS TINGKAT PEMULA DALAM PEMBELAJARAN PENCAK SILAT
}

\author{
Wiwin Hariyanti ${ }^{1}$, I Ketut Budaya Astra ${ }^{2}$, I Gede Suwiwa ${ }^{3}$ \\ ${ }^{123}$ Program Studi Pendidikan Jasmani, Kesehatan dan Rekreasi \\ Universitas Pendidikan Ganesha \\ Singaraja, Indonesia \\ e-mail: wiwin1408@gmail.com, astra_budaya@yahoo.com, \\ suwiwagede@gmail.com\}@undiksha.ac.id
}

\begin{abstract}
Abstrak
Penelitian ini bertujuan untuk mengembangkan model latihan fleksibilitas tingkat pemula dalam pembelajaran pencak silat. Jenis penelitian ini adalah penelitian pengembangan. Prosedur pengembangan model latihan menggunakan model Borg \& Gall meliputi 10 tahap yaitu: tahap penelitian dan pengumpulan informasi, tahap perencanaan, tahap mengembangan bentuk pendahuluan produk, tahap uji lapangan persiapan, tahap revisi produk utama, tahap uji lapangan utama, tahap pelaksanaan revisi produk, tahap uji lapangan operasional, tahap revisi produk akhir, serta tahap penyebaran dan pengimplementasian. Langkah validasi bahan ajar mengadopsi model Borg \& Gall yaitu: uji lapangan persiapan, uji lapangan utama, uji lapangan operasional dan peneliti menambahkan uji ahli isi serta uji ahli mata pelajaran agar hasil penelitian lebih signifikan. Teknik analisis data yang digunakan yaitu deskriptif kuantitatif. Model latihan fleksibilitas tingkat pemula yang dirancang yaitu dalam bentuk modul yang terdiri dari gambar sikap awal, sikap pelaksanaan dan sikap akhir serta deskripsi dalam bentuk teks di sebelahnya yang merupakan deskripsi langkah-langkah melakukan gerakan pada gambar serta tujuan melakukan gerakan tersebut. Berdasarkan tanggapan ahli isi menunjukkan bahwa validasi model latihan fleksibilitas tingkat pemula adalah sangat baik dengan persentase $100 \%$. Tanggapan siswa dalam uji lapangan persiapan memperoleh persentase $95 \%$ berada pada kualifikasi sangat baik, dalam uji lapangan utama memperoleh persentase $96,64 \%$ berada pada kualifikasi sangat baik dan dalam uji lapangan operasional memperoleh $97,35 \%$ berada pada kualifikasi sangat baik. Berdasarkan hasil penelitian disimpulkan bahwa model latihan fleksibilitas tingkat pemula dalam pembelajaran pencak silat menurut uji ahli isi, uji ahli mata pelajaran PJOK, uji lapangan persiapan, uji lapangan utama dan uji lapangan operasional layak digunakan dalam latihan pemanasan sebelum melakukan gerakan pencak silat. Penelitian ini diharapkan dapat dieksperimenkan untuk mengetahui keefektifannya dalam meningkatkan hasil belajar dan prestasi siswa.
\end{abstract}

Kata-kata kunci: model latihan, fleksibilitas, pencak silat

\begin{abstract}
This study aims to develop a beginner level flexibility training model in pencak silat learning. This type of research is development research. The procedure for developing the training model using the Borg \& Gall model includes 10 stages, namely: the research and information collection stage, the planning stage, the stage of developing
\end{abstract}


the product introduction, the preparation field test phase, the main product revision stage, the main field test phase, the product revision stage, operational field test, final product revision stage, and stage of deployment and implementation. The validation step of the teaching material adopts the Borg \& Gall model, namely: preparation field test, main field test, operational field test and the researcher adds content expert test and subject matter test so that the research results are more significant. The data analysis technique used is descriptive quantitative. Beginner level flexibility training models that are designed are in the form of modules consisting of initial attitude images, the attitude of implementation and the final attitude of the description in the form of the text next to it which is a description of the step to make a movement in the image and the purpose of doing the movement. based on the content experts response, it was shown that the validation of the beginner level flexibility training model was very good with a percentage of $100 \%$. The response of students in the preparation field test obtained a percentage of $95 \%$ in very good qualifications, in the main field test the percentage of $96.64 \%$ was in very good qualifications and in the operational field test $97.35 \%$ were in excellent qualification. Based on the results of the study concluded that the beginner level flexibility training model in pencak silat learning is feasible to use according to the content expert test, PJOK subject matter test, preparation field test, main field test and operational field test. This research is expected to be experimented to determine its effectiveness in improving learning outcomes and student achievement.

Keywords: training model, flexibility, pencak silat

\section{PENDAHULUAN}

Pencak silat adalah salah satu cabang olahraga beladiri yang berakar dari bangsa Melayu. Menurut Weda (2015:3), mengatakan bahwa pencak silat adalah hasil budaya manusia Indonesia untuk membela atau mempertahankan eksistensi (kemandirian) dan intengritasnya (manunggalnya) terhadap lingkungan hidup atau alam sekitarnya untuk mencapai keselarasan hidup guna meningkatkan iman dan taqwa kepada Tuhan Yang maha Esa.

Dalam pertandingan pencak silat terdapat empat cabang, yaitu: tanding, tunggal, ganda dan beregu. Terdapat tiga aspek yang harus disiapkan untuk mencapai prestasi dalam cabang olahraga pencak silat, yaitu: fisik, teknik dan mental. Di antara ke tiga aspek tersebut saling berkesinambungan dan tidak dapat dipisahkan. Fisik yang kuat harus diikuti dengan teknik yang bagus dan di dukung dengan mental yang bagus. Aspek pertama yang harus disiapkan adalah aspek fisik. Fisik yang harus dimiliki ialah fisik yang bagus dan kuat. Fisik yang kuat dapat menunjang prestasi atlet, begitu sebaliknya jika fisiknya lemah maka akan menghambat prestasi atlet. Untuk mencapai fisik yang bagus dan kuat diperlukan aktivitas fisik yang harus disiapkan oleh seorang pesilat.

Aktivitas fisik merupakan gerakan tubuh akibat aktivitas otot-otot rangka yang mengakibatkan pengeluaran energi. Terdapat beberapa komponen fisik yang harus disiapkan yaitu: kecepatan, kelincahan, ketepatan, keseimbangan, fleksibilitas, power, kekuatan dan koordinasi. Salah satu komponen fisik yang penting ialah fleksibilitas. "Fleksibilitas adalah efektivitas seseorang dalam penyesuaian diri untuk segala aktivitas dengan penguluran tubuh yang luas" 
(Sajoto, 1995:9). $\quad$ Fleksibiltas dipengaruhi oleh banyak faktor yaitu otot, tendon, ligamen, usia, jenis kelamin, suhu tubuh dan struktur sendi. Fleksibilitas yang kurang dapat menyebabkan gerakan lebih lamban dan rentan terhadap cedera otot, ligamen dan jaringan lainnya.

Selain fisik yang kuat, kondisi tubuh yang siap untuk melakukan teknik-teknik gerakan pencak silat harus disiapkan juga. Untuk mencapai kesiapan tubuh dalam melakukan gerakan tersebut diperlukan pemanasan yang baik dan benar sesuai prosedur. Hal ini bertujuan untuk mengurangi resiko terjadinya cedera. Arifin (2015: 2), menyatakan bahwa pemanasan adalah menyiapkan tubuh untuk melakukan aktivitas fisik. Jika pemanasan membantu tubuh kita dalam membuat transisi dari keadaan istirahat ke aktivitas sedang maka pendinginan membuatnya kembali menjadi relax dan tenang setelah tubuh melakukan aktivitas latihan maupun pertandingan.

Pemanasan dapat dilakukan secara umum maupun spesifik. Pemanasan secara umum (general warm-up) tidak melibatkan gerakan spesifik, hanya dilakukan dengan melakukan serangkaian olahraga ringan seperti push-up, memutarkan tangan, lari di tempat, melompat, dan squatjump. Sedangkan pemanasan spesifik dilakukan dengan melakukan beberapa gerakan yang akan dilakukan saat berolahraga, hanya saja dengan intensitas yang lebih ringan.

Peneliti mengumpulkan informasi mengenai keadaan di lapangan melalui wawancara pada guru mata pelajaran PJOK dan melakukan analisis kebutuhan di sekolah. Berdasarkan hasil observasi di beberapa sekolah yaitu: SMA LAB UNDIKSHA, SMAN 2 Singaraja, SMKN 1 Singaraja, SMAN 1 Singaraja, SMKN 3 Singaraja,
SMKN 1 Sukasada dan SMAN 1 Sukasada ditemukan masalah yang sama. Secara umum, pemanasan yang dilakukan dalam pembelajaran pencak silat masih bersifat umum, yaitu pemanasan statis dan pemanasan dinamis. Latihan fleksibilitas dilakukan namun tidak banyak dan tidak spesifik. Variasi model latihan fleksibilitas di sekolah masih sangat minim sehingga hal itu dapat mengakibatkan proses pembelajaran yang tidak optimal atau merasakan gerakan yang dilakukan sangat sulit karena belum terbiasa dengan gerakan tersebut dan kurangnya latihan kelenturan pada saat melakukan pemanasan. Di beberapa sekolah pembelajaran pencak silat bahkan tidak diajarkan karena keterbatasan waktu, tempat, sarana dan prasarana serta keterbatasan pengetahuan guru terkait dengan pengetahuan pencak silat.

Berdasarkan hasil observasi tersebut, model latihan fleksibilitas tingkat pemula dibutuhkan di sekolahsekolah karena dapat digunakan sebagai sumber belajar mandiri, melatih kelenturan bagi diri siswa sehingga mempermudah dalam melakukan gerakan-gerakan dalam pencak silat sehingga dapat meningkatkan prestasi dan dapat mengurangi resiko terjadinya cedera. Dengan tersedianya model latihan fleksibilitas yang sesuai dengan kebutuhan karakteristik siswa, maka diharapakan pembelajaran akan berlangsung secara efektif dan efisien. Melalui model latihan fleksibilitas tingkat pemula, ditampilkan model latihan fleksibilitas yang tentunya model latihan tersebut berkaitan dengan gerakan-gerakan pencak silat yang dipelajari. Model latihan ini cocok digunakan supaya siswa, guru atau pelatih, seseorang yang baru belajar latihan pencak silat lebih aktif dalam proses latihan maupun pembelajaran. Melalui model latihan 
tersebut, siswa lebih gampang dalam belajar dan dapat melakukan pemanasan secara optimal sehingga dapat mengurangi resiko terjadinya cedera. Oleh karena itu, peneliti menggagas sebuah penelitian yang berjudul "Pengembangan Model Latihan Fleksibilitas Tingkat Pemula dalam Pembelajaran Pencak Silat".

Berpijak pada latar belakang di atas rumusan masalah dalam penelitian ini yaitu: 1) bagaimanakah merancang desain model latihan yang mudah dimengerti dari aspek materi, aspek tampilan dan aspek daya tarik untuk model latihan fleksibilitas tingkat pemula dalam pembelajaran pencak silat?, 2) bagaimanakah tanggapan ahli isi terhadap model latihan fleksibilitas tingkat pemula dalam pembelajaran pencak silat?, 3) bagaimanakah tanggapan siswa dalam uji lapangan persiapan, uji lapangan utama dan uji lapangan operasional terhadap model latihan fleksibilitas tingkat pemula dalam pembelajaran pencak silat yang dikembangkan?.

Adapun tujuan dari penelitian dalam penelitian ini yaitu: 1) untuk medeskripsikan rancang desain model latihan yang mudah dimengerti dari aspek materi, aspek tampilan dan aspek daya tarik untuk model latihan fleksibilitas tingkat pemula dalam pembelajaran pencak silat, 2) untuk mendeskripsikan tanggapan ahli isi dan ahli mata pelajaran terhadap model latihan fleksibilitas tingkat pemula dalam pembelajaran pencak silat, 3) untuk mendeskripsikan tanggapan siswa dalam uji lapangan persiapan, uji lapangan utama dan uji lapangan operasional terhadap model latihan fleksibilitas tingkat pemula dalam pembelajaran pencak silat yang dikembangkan.

Teori-teori yang melandasi penelitian ini adalah pembelajaran dalam pendidikan jasmani, olahraga dan kesehatan, pengembangan model latihan fleksibiltas dan pencak silat.

Tegeh dan Jampel (2017:19), mengatakan bahwa penelitian pegembangan adalah upaya untuk mengembangkan dan menghasilkan suatu produk berupa materi, media, alat atau strategi pembelajaran, yang digunakan untuk mengatasi pembelajaran di kelas atau laboratorium dan bukan untuk menguji teori.

Pengertian model adalah suatu cara yang digunakan dalam melaksanakan suatu pekerjaan untuk memperoleh hasil yang ideal sesuai dengan yang dikehendaki dan menggambarkan sesuatu yang diusahakan untuk dicapai.

Latihan adalah proses pengulangan aktivitas fisik atau kerja secara baik dan benar untuk meningkatkan pencapaian penampilan yang optimal guna meraih prestasi setinggi-tingginya.

Fleksibilitas adalah efektivitas seseorang dalam penyesuaian diri untuk segala aktivitas dan bergerak dengan leluasa dan nyaman dalam ruang gerak maksimal yang diharapkan.

Pengertian model latihan fleksibilitas adalah suatu cara yang digunakan dalam aktivitas fisik agar dapat melakukan segala aktivitas gerak dengan leluasa dan nyaman untuk meraih prestasi setinggi-tingginya.

\section{METODE}

Model pembuatan produk dalam penelitian pengembangan ini adalah model Borg \& Gall yang terdiri dari 10 tahapan (Tegeh dan Jampel, 2017:64). Pemilihan model ini didasarkan atas pertimbangan bahwa adanya kesesuaian antara metode pengembangan dengan produk yang dikembangkan. Keunggulan model Borg \& Gall itu sendiri yaitu mampu menghasilkan 
suatu produk yang memiliki nilai validitas tinggi, karena melalui serangkaian uji coba dilapangan dan divalidasi ahli. Berikut tahapan Model Borg \& Gall meliputi:

\begin{tabular}{|c|c|}
\hline & $\begin{array}{l}\text { 1. Penelitian dan } \\
\text { pengumpulan } \\
\text { informasi }\end{array}$ \\
\hline & 2. Perencanaan \\
\hline & $\begin{array}{l}\text { 3. } \text { Mengembangkan } \\
\text { bentuk pendahuluan } \\
\text { produk }\end{array}$ \\
\hline & $\begin{array}{l}\text { 4. Uji lapangan } \\
\text { persiapan }\end{array}$ \\
\hline \multirow[t]{6}{*}{$\begin{array}{l}\text { Borg \& } \\
\text { Gall }\end{array}$} & 5. Revisi produk utama \\
\hline & 6. Uji lapangan utama \\
\hline & $\begin{array}{l}\text { 7. Pelaksanaan revisi } \\
\text { produk }\end{array}$ \\
\hline & $\begin{array}{l}\text { 8. Uji lapangan } \\
\text { operasional }\end{array}$ \\
\hline & 9. Revisi produk akhir \\
\hline & $\begin{array}{l}\text { 10. Penyebaran dan } \\
\text { pengimplementasian }\end{array}$ \\
\hline
\end{tabular}

1. Penelitian dan pengumpulan informasi yaitu termasuk kajian pustaka, pengamatan kelas, penyiapan laporan sebagai bagian dari seni dan analisis kebutuhan.

2. Perencanaan yaitu mendefinisikan keterampilan, pernyataan tujuan dan tes skala kecil yang mungkin dikerjakan.

3. Mengembangkan bentuk pendahuluan produk artinya pada tahap ini termasuk persiapan materi pembelajaran, handbook dan alat evaluasi.
4. Uji lapangan persiapan yaitu dilakukan pada 1 sampai 3 sekolah, menggunakan 6 sampai 12 subyek.

5. Revisi produk utama yaitu sebagaimana disarankan oleh hasil uji lapangan persiapan.

6. Uji lapangan utama yaitu dilakukan pada 5 sampai 15 sekolah dengan 30 sampai 100 subyek.

7. Pelaksanaan revisi produk yaitu sebagaimana disarankan oleh hasil uji lapangan utama.

8. Uji lapangan operasional dilakukan pada 10 sampai 30 sekolah meliputi 40 sampai 200 subyek.

9. Revisi produk akhir dilakukan sebagaimana disarankan oleh hasil uji lapangan operasional.

10. Penyebaran dan pengimplementasian yaitu melaporkan produk pada pertemuan profesional dan dalam jurnal. Bekerja dengan penerbit yang memangku distribusi komersial. Memonitor distribusi untuk meningkatkan kontrol kualitas.

Jumlah responden yang menguji coba produk yaitu dua orang ahli isi, tiga orang ahli mata pelajaran, enam siswa dalam uji lapangan persiapan dengan menggunakan tiga sekolah, tiga puluh siswa dalam uji lapangan utama dengan menggunakan lima sekolah dan empat puluh siswa dalam uji lapangan operasional dengan menggunakan sepuluh sekolah.

Instrumen yang digunakan dalam penelitian ini adalah angket dalam bentuk pertanyaan terkait model latihan fleksibilitas tingkat pemula dalam pembelajaran pencak silat. Angket tersebut berisi pertayaanpertanyaan terkait model latihan fleksibilitas tingkat pemula dan petunjuk pelaksanaan model latihan fleksibilitas tingkat pemula. Angket digunakan untuk mengumpulkan data hasil review dari ahli isi dan ahli mata 
pelajaran, uji lapangan persiapan, uji lapangan utama dan uji lapangan operasional.

Penelitian pengembangan ini menggunakan teknik analisis deskriptif kuantitatif. Teknik analisis ini digunakan untuk mengolah data yang diperoleh melalui angket dalam bentuk Deskriptif persentase.

\section{HASIL DAN PEMBAHASAN}

Pengembangan model latihan fleksibilitas tingkat pemula dalam pembelajaran pencak silat berawal dari permasalahan yang ditemukan pada beberapa sekolah yang diperoleh dari hasil wawancara guru mata pelajaran PJOK.

Oleh karena itu, berdasarkan permasalahan yang diperoleh, maka peneliti mengembangkan sebuah model latihan yang diharapkan dapat mengatasi permasalahan pada pembelajaran PJOK tersebut yaitu berupa model latihan fleksibilitas tingkat pemula dalam pembelajaran pencak silat.

Rancang desain model latihan fleksibilitas tingkat pemula dalam pembelajaran pencak silat menggunakan model Borg \& Gall yang menghasilkan model latihan fleksibilitas tingkat pemula dalam pembelajaran pencak silat. Adapun tahap uji coba model latihan yang telah dilakukan yaitu uji coba ahli isi, uji coba ahli mata pelajaran, uji lapangan persiapan, uji lapangan utama dan uji lapangan operasional. Semua tahapan tersebut dilakukan guna menyempurnakan model latihan fleksibilitas tingkat pemula sehingga benar-benar mampu dan layak digunakan dalam pembelajaran PJOK materi pencak silat. Hasil penelitian ini menunjukkan bahwa validitas menurut tanggapan para ahli terhadap model latihan fleksibilitas tingkat pemula dalam pembelajaran pencak silat yang dikembangkan adalah sebagai berikut: 1) menurut ahli isi memperoleh presentase $100 \%$ dengan kualifikasi sangat baik dan 2) menurut ahli mata pelajaran PJOK memperoleh presentase 98,66\% dengan kualifikasi sangat baik. Sedangkan validitas model latihan ditinjau dari hasil uji lapangan persiapan memperoleh presentase $95 \%$ dengan kualifikasi sangat baik, uji lapangan utama memperoleh presentase 96,64\% dengan kualifikasi sangat baik, dan uji lapangan operasional memperoleh presentase $97,35 \%$ dengan kualifikasi sangat baik.

Berdasarkan hasil penelitian tersebut, maka model latihan fleksibilitas tingkat pemula ini dianggap valid dan layak menurut uji coba ahli, uji lapangan persiapan, uji lapangan utama dan uji lapangan operasional.

Berdasarkan pertimbanganpertimbangan teoritik dan empiris, pengembangan model latihan fleksibilitas tingkat pemula ini memiliki beberapa implikasi, yaitu:

1. Dapat digunakan sebagai sumber belajar mandiri, melatih kelenturan bagi diri siswa sehingga mempermudah dalam melakukan gerakan-gerakan dalam pencak silat sehingga dapat meningkatkan prestasi.

2. Memberikan guru atau pelatih model latihan alternatif yang dapat digunakan dalam proses pembelajaran.

3. Mempercepat penguasaan gerakan dalam pembelajaran pencak silat.

4. Dapat meningkatkan semangat belajar siswa sehingga dapat membantu meningkatkan hasil belajar dan latihan siswa.

5. Mengurangi resiko terjadinya cedera. 


\section{SIMPULAN DAN SARAN}

Rancang desain model latihan fleksibilitas tingkat pemula dalam pembelajaran pencak silat menggunakan model Borg \& Gall dengan tahapannya yaitu (1) penelitian dan pengumpulan informasi, (2) perencanaan, (3) mengembangkan bentuk pendahuluan produk, (4) uji lapangan persiapan, (5) revisi produk utama, (6) uji lapangan utama, (7) pelaksanaan revisi produk, (8) uji lapangan operasional, (9) revisi produk akhir dan (10) penyebaran dan pengimplementasian. Dari tahapan tersebut menghasilkan model latihan fleksibilitas tingkat pemula dalam pembelajaran pencak silat dalam bentuk modul yang terdiri dari gambar sikap awal, sikap pelaksanaan dan sikap akhir deskripsi dalam bentuk teks di sebelahnya yang merupakan deskripsi langkah-langkah melakukan gerakan pada gambar serta tujuan melakukan gerakan tersebut.

Validitas menurut para ahli terhadap model latihan fleksibilitas tingkat pemula dalam pembelajaran pencak silat yang dikembangkan adalah sebagai berikut: (1) menurut ahli isi memperoleh presentase $100 \%$ dengan kualifikasi sangat baik dan (2) menurut ahli mata pelajaran PJOK memperoleh presentase $98,66 \%$ dengan kualifikasi sangat baik.

Validitas menurut para siswa terhadap model latihan fleksibilitas tingkat pemula dalam pembelajaran pencak silat yang dikembangkan adalah (1) berdasarkan uji lapangan persiapan memperoleh presentase $95 \%$ dengan kualifikasi sangat baik, (2) berdasarkan uji lapangan utama memperoleh presentase 96,64\% dengan kualifikasi sangat baik, dan (3) berdasarkan uji lapangan operasional memperoleh presentase $97,35 \%$ dengan kualifikasi sangat baik.
Adapun saran yang disampaikan berdasarkan pengembangan multimedia interaktif berbasis game edukasi ini adalah: bagi siswa disarankan menggunakan model latihan fleksibilitas tingkat pemula dalam pembelajaran pencak silat ini sebagai salah satu sumber belajar belajar mandiri, sehingga dapat melatih kelenturan bagi diri siswa dan mempermudah dalam melakukan gerakan-gerakan dalam pencak silat sehingga dapat meningkatkan prestasi. Bagi guru disarankan memanfaatkan model latihan fleksibilitas tingkat pemula dalam pembelajaran pencak silat ini pada pembelajaran mata pelajaran PJOK khususnya materi pencak silat sebagai model latihan alternatif yang dapat digunakan dalam proses pembelajaran untuk meningkatkan motivasi belajar siswa guna meningkatkan kemampuan belajar PJOK. Bagi sekolah disarankan agar menyimpan produk pengembangan ini dengan baik, sehingga bisa menjadi salah satu koleksi model latihan yang dapat digunakan di sekolah. Bagi peneliti lainnya, penelitian ini menghasilkan model latihan fleksibilitas tingkat pemula yang teruji validitasnya, diharapkan peneliti lain dapat melakukan eksperimen untuk mengetahui efektifitas model latihan fleksibilitas tingkat pemula dalam pembelajaran pencak silat ini untuk meningkatkan prestasi belajar siswa.

\section{DAFTAR PUSTAKA}

Arifin, Zenal. 2015. Aktivitas Pemanasan dan Pendinginan pada Siswa

Ekstrakurikuler Olahraga di SMP Negeri Se-Kecamatan Semarang Timur Kota Semarang. Journal of Physical Education, Sport, Health and Recreation. 4 (2): 2 . 
Sajoto. 1995. Peningkatan \& Pembinaan Kekuatan Kondisi Fisik dalam Olah Raga. Semarang: Dahara Prize

Tegeh, I Made dan Jampel, I Nyoman. 2017. Metode Penelitian Pengembangan. Singaraja: UNDIKSHA

Weda, Moh Nurkholis. 2015. Implementasi Nilai Nilai Pembentukan Sikap dalam Pencak Silat Terhadap Perilaku Mahasiswa Prodi Penjaskesrek UNP Kediri. JURNAL SPORTIF. VOL. 1 (1): 3. 